\title{
Combined treatment in Ramsay Hunt syndrome: evaluation of clinic and prognosis
}

\author{
Ramsay Hunt sendromunda kombine tedavi: Klinik ve prognozun değerlendirilmesi \\ Ercan Pınar, Abdulkadir İmre, Yüksel Olgun, Ahmet Ata Ece, Murat Songu, Hale Aslan \\ Department of Otorbinolaryngology, Izmir Katip Çelebi University Atatïrk Training and Research Hospital, Izmir, Turkey
}

\begin{abstract}
Objective: We retrospectively analysed clinical characteristics, treatment and outcomes of the patients with Ramsay Hunt syndrome.

Methods: Twelve patients with Ramsay Hunt syndrome were analysed retrospectively. Data recorded included sex, age, time from first onset to initial treatment and clinical outcomes. The HouseBrackmann scale was used to assess initial facial nerve dysfunction and final facial nerve impairment. All patients were treated with oral steroids and oral acyclovir.

Results: There were 7 male and 5 female patients. Mean age was 59 (range: 21 to 68 ) years. The main symptom was acute facial palsy. House-Brackmann classification of facial nerve function ranged from grade III to VI before treatment. The median baseline HouseBrackmann grade was 4.5 and it was 2.33 after the treatment in all patients. Recovery rate of facial palsy was lower in patients with House-Brackmann grades V and VI.

Conclusion: In this syndrome, the prognosis of facial palsy depends on the initial symptoms and clinical findings. The prognosis was poorer in severe palsy and patients with comorbid disease(s).
\end{abstract}

Keywords: Ramsay Hunt syndrome, treatment, prognosis.

Ramsay Hunt syndrome (RHS) is a disease with involvement of the seventh and eighth cranial nerves and characterized by acute facial palsy and inner ear dysfunction with a herpetic eruption on the auricula and external ear canal. Ramsay Hunt reported the first case in 1907. This syndrome is caused by reactivation of the latent varicella zoster virus in the geniculate ganglion of the facial nerve. ${ }^{[1]}$

\begin{abstract}
Özet
Amaç: Çalışmanın amacı Ramsay Hunt sendromu tanısı alan hastaların klinik özelliklerini, tedavi ve sonuçlarını retrospektif olarak analiz etmektir.

Yöntem: Ramsay Hunt sendromlu 12 hasta retrospektif olarak analiz edildi. Hastaların cinsiyeti, yaşı, tedaviye ilk başvuru süresi ve klinik sonuçları kaydedildi. Fasiyal disfonksiyonun değerlendirilmesinde House-Brackmann evreleme sistemi kullanıldı. Bütün hastalar oral steroid ve acyclovir ile tedavi edildi.

Bulgular: Hastalarımızın 7'si erkek, 5'i kadın idi. Hastalarımızın yaş ortalaması 59 olarak bulundu (21-68 arasi). En önemli semptom akut fasiyal paralizi idi. Hastaların tedavi öncesi House-Brackmann skalası III ile VI arasında değişmekteydi. Tüm hastalarda ilk ortalama HouseBrackmann skalası değeri 4.5, tedavi sonrası 2.33 idi. House Brackmann skalası V ve VI olan hastalarda fasiyal paralizinin dönme riski daha düşüktü.

Sonuç: Ramsay Hunt sendromunda, fasiyal paralizinin prognozu ilk semptomlara ve klinik bulgulara bağlıdır. Prognoz ciddi paralizi ve komorbid hastalığı olanlarda daha kötüdür.
\end{abstract}

Anahtar sözcükler: Ramsay Hunt sendromu, tedavi, prognoz.

This syndrome represents the second most common cause of atraumatic peripheral facial palsy. It is responsible for $2-10 \%$ of all cases of acute peripheral facial palsy. ${ }^{[2]}$ The treatment of this syndrome is empiric. Various authors have reported several treatment protocols including corticosteroids, vasodilators and antiviral agents..$^{[3-5]}$

The present study describes the clinical presentation, treatment and clinical outcomes of this rare disease.
Correspondence: Ercan Pınar, MD. Department of Otorhinolaryngology, Izmir Katip Çelebi University Atatürk Training and Research Hospital, Izmir, Turkey.

e-mail: epinar66@yahoo.com

Received: December 1, 2014; Accepted: December 22, 2014
Online available at: www.jmedupdates.org doi:10.2399/jmu.2014003005 QR code: 


\section{Materials and Methods}

This retrospective study included 12 patients who presented with RHS between March 2006 and October 2014. Patients were diagnosed with Ramsay Hunt syndrome if they had peripheral facial palsy and vesicles around the ear. Data recorded included sex, age, time from the first onset to initial treatment and clinical outcomes. The HouseBrackmann scale was used to assess initial facial nerve dysfunction and final facial nerve impairment. All patients underwent electroneurography (ENoG) 3 days after onset of palsy and all were followed up with electromyography (EMG) 3 weeks after the onset. Patients were followed up until recovery or for 6 months. Recovery was defined as attainment of House-Brackmann grade I or II.

Pure tone audiometry and neurology consultation was performed in all patients before treatment to assess the eight and other cranial nerve functions. Magnetic resonance imaging (MRI) was also performed.

All patients had low-salt diet. Patients were treated with oral steroids $(1 \mathrm{mg} / \mathrm{kg})$ by tapering dose regimen. Oral acyclovir (4000 mg/d for 7 days) was combined with oral steroids. Diabetic patients received the same dose of steroids under the medical care of an endocrinologist.

\section{Results}

There were seven male and five female patients in this retrospective study with a median age of 59 (range: 21 to 68) years. All patients admitted to our clinic within $2-5$ days after the onset of the symptoms and received the treatment protocol. The median initial House-Brackmann grade was 4.5 , while it was 2.33 after the treatment in all patients. Hearing loss and rotational vertigo were seen in six patients. Patients' characteristics are shown in Table 1.

Overall recovery rate was $75 \%$ in this study. Recovery rate was lower in patients with a an ENoG of $>90 \%$ compared with ENoG $<90 \%$. Similarly, worse initial facial palsy was associated with lower recovery rate. Initial House-Brackman grade $\mathrm{V}$ or more had lower recovery rates. Recovery rate was $83.3 \%$ in patients with HouseBrackmann grade $\leq 4$; however, recovery rate was $33.3 \%$ in grades $\geq V$. Five patients had comorbid diseases (diabetes mellitus, hypertension). Patients with comorbid disease(s) had also lower recovery rates (Table 2).

\section{Discussion}

The standard treatment of RSH syndrome is corticosteroid and antiviral therapy. Corticosteroid therapy relieves pain, reduces vertigo, decreases the incidence of postherpetic neuralgia. It also reduces facial nerve inflammation and edema. Acyclovir, a synthetic acyclic purine nucleoside ana$\log$, is a selective inhibitor of herpes simplex virus types 1 and $2 .^{[6]}$

Combined therapy is the treatment of choice in RSH syndrome. Uscategui et al. demonstrated a statistically significant difference between combined acyclovir-corticosteroid therapy and treatment with corticosteroids alone. ${ }^{[7]}$ Similarly, Kinishi et al. reported that median recovery rate from facial palsy was $62 \%$ in patients treated with corticosteroids alone, however, with both acyclovir and steroid therapy, the receive rate was 90 percent. ${ }^{[6]}$ The recovery rate was $84 \%$ in the study by Lee et al ${ }^{[8]}$ In our study, we treated our patients with combined therapy and the overall recovery rate was 75 percent.

We found that initial palsy episodes with lower grades of palsy were associated with a higher recovery rate. The median initial House-Brackmann grade was 4.5. HouseBrackmann grade was 2.33 after the treatment. Recovery rate was lower in patients with grade $\mathrm{V}$ or more compared with mild cases. Similar to our results, Ko et al. and

Table 1. Characteristics of patients with Ramsay Hunt syndrome.

\begin{tabular}{llc}
\hline Patients $\mathbf{( n = 1 2 )}$ & $\mathbf{n}(\%)$ \\
\hline Gender & Male & $7(58.3 \%)$ \\
& Female & $5(41.6 \%)$ \\
Mean age & 59 \\
Initial HB & 4.5 \\
HB after treatment & 2.33 \\
Vertigo & 5 \\
Hearing loss & 6 \\
Comorbid disease (DM, HT) & 5 \\
\hline
\end{tabular}

DM: diabetes mellitus, HB: House-Brackmann, HT: hypertension

Table 2. Recovery rates of patients after treatment.

\begin{tabular}{lcc}
\hline Patients $(\mathbf{n = 1 2 )}$ & Recovery rate (\%) \\
\hline HB III-IV $(n=6)$ & $83.3 \%$ \\
HB V-VI $(n=6)$ & $33.3 \%$ \\
EnoG $>90 \%(n=8)$ & & $87.5 \%$ \\
EnoG $<90 \%(n=4)$ & & $50 \%$ \\
Comorbid disease & Yes: $5(41.6 \%)$ & $80 \%$ \\
& No: $7(58.3 \%)$ & $71.4 \%$ \\
\hline
\end{tabular}


Zainine et al. found that incomplete paralysis had higher recovery rates. ${ }^{[4,9]}$ Coulson et al. also reported that improvement was less likely for patients who initially had higher House-Brackmann scores. ${ }^{[10]}$

Patients with comorbid disease(s) had poorer prognoses than those without comorbid disease(s). This can be attributable to the presence of diabetic neuropathy. In our study, comorbid disease had lower recovery rate. Yeo et al. found that recovery rates were significantly lower in patients with comorbid disease(s). ${ }^{[1]}$

Electroneurography is usually used to measure nerve injury and disease progression in facial palsy. Electroneurography is generally effective when performed more than 3 days after the onset of palsy, when neural damage can be accurately determined. ${ }^{[8]}$ We performed EnoG, 3 days after the onset and found a relationship between ENoG results and patient prognosis. Anpalahan et al. reported that ENoG correctly predicted recovery in $98 \%$ of their patients when the neural response of the affected side was more than $25 \%$ of the unaffected side. ${ }^{[12]}$ Based on the data of Byun et al., non-recovery is predicted in patients with ENoG values greater than $78 \%$ in RHS. ${ }^{[13]}$ Morishima et al. also reported the prognostic value of ENoG in RHS. ${ }^{[14]}$

\section{Conclusion}

Combined treatment in RHS is the treatment of choice. Patients with comorbid disease(s) in RHS have poorer prognosis. In addition, initial House-Brackmann grades of $\geq \mathrm{V}$ and worse $\mathrm{ENoG}$ response results in lower recovery rates.

Conflict of Interest: No conflicts declared.

\section{References}

1. Robillard RB, Hilsinger RL, Adour KK. Ramsay Hunt facial paralysis: clinical analyses of 185 patients. Otolaryngol Head Neck Surg 1986:95;292-7.
2. Adour KK. Otologic complications of herpes zoster. Ann Neurol 1994;35:62-4.

3. Kansu L, Yilmaz I. Herpes zoster oticus (Ramsay Hunt syndrome) in children: case report and literature review. Int J Ped Otorhinolaryngol 2012:76;772-6.

4. Ko JY, Sheen TS, Hsu MM. Herpes zoster oticus treated with acyclovir and prednisolone: clinical manifestations and analysis of prognostic factors. Clin Otolaryngol Allied Sci 2000;25:139-42.

5. Wagner G, Klinge H, Max Sachse M. Ramsay Hunt syndrome. J Dtsch Dermatol Ges 2012;10:238-43.

6. Kinishi M, Amatsu M, Mohri M, Saito M, Hasegawa T, Hasegawa $\mathrm{S}$. Acyclovir improves recovery rate of facial nerve palsy in Ramsay Hunt syndrome. Auris Nasus Larynx 2001;28:223-6.

7. Uscategui T, Doree C, Chamberlain IJ,Burton MJ. Antiviral therapy for Ramsay Hunt syndrome (herpes zoster oticus with facial palsy) in adults. Cochrane Database Syst Rev 2008;8(4): CD006851.

8. Lee DH, Chae SY, Park YS, Yeo SW. Prognostic value of electroneurography in Bell's palsy and Ramsay-Hunt's syndrome. Clin Otolaryngol 2006;31:144-8.

9. Zainine R, Sellami M, Charfeddine A, Beltaief N, Sahtout S, Besbes G. Ramsay Hunt syndrome. Eur Ann Otorhinolaryngol Head Neck Dis 2012;129:22-5.

10. Coulson S, Croxson GR, Adams R, Oey V. Prognostic factors in herpes zoster oticus (Ramsay Hunt syndrome). Otol Neurotol 201;32:1025-30.

11. Yeo SW, Lee DH, Jun BC, Chang KH, Park YS. Analysis of prognostic factors in Bell's palsy and Ramsay Hunt syndrome. Auris Nasus Larynx 2007;34:159-64.

12. Anpalahan V, Redhead J. Acyclovir and prednisolone combination treatment in Bell's palsy. Aust J Otolaryngol 2000;3:476-8.

13. Byun H, Cho YS, Jang JY, Chung KW, Hwang S, Chung WH, Hong SH. Value of electroneurography as a prognostic indicator for recovery in acute severe inflammatory facial paralysis: a prospective study of Bell's palsy and Ramsay Hunt syndrome. Laryngoscope 2013;123:2526-32.

14. Morishima N, Yagi R, Shimizu K, Ota S. Prognostic factors of synkinesis after Bell's palsy and Ramsay Hunt syndrome. Auris Nasus Larynx 2013;40:431-4.

This is an open access article distributed under the terms of the Creative Commons Attribution-NonCommercial-NoDerivs 3.0 Unported (CC BYNC-ND3.0) Licence (http://creativecommons.org/licenses/by-nc-nd/3.0/) which permits unrestricted noncommercial use, distribution, and reproduction in any medium, provided the original work is properly cited.

Please cite this article as: Pınar E, İmre A, Olgun Y, Ece AA, Songu M, Aslan H. Combined treatment in Ramsay Hunt syndrome: evaluation of clinic and prognosis. J Med Updates 2014;4(3):110-112. 